Visar HOXHA

\title{
Cultural factors affecting urban planners' intentions to regulate public space in Prishtina, Kosovo
}

Cultural factors can affect urban planners' intentions to regulate public space in a particular way. The effects of cultural identity or ideology on urban planning are significant, but are often overlooked because they are difficult to quantify. This study verifies which factors affect planners' perceptions in Prishtina, which are further reflected in their intentions behind designing and producing space. The factors are adopted from previous studies and are national identity, ethnic nationalism, social constructs and political pressure. We use qualitative research with cross-case analysis. By using purposive sampling and conducting semi-structured interviews with selected urban planners in Prishtina, the study shows the effects of such factors on urban planners' perceptions and intentions. National identity is the most important factor affecting planners' perceptions, followed by political pressure, whereas ethnic nationalism and social constructs are much less important. In addition, the structural relativity of planners' perceptions and intentions has positive effects. The results of this study highlight elements that urban planners in Kosovo should consider and provide insights for future studies.

Key words: cultural factors, planners' perceptions, planners' intentions, Kosovo 


\section{Introduction}

The purpose of urban planning is to regulate the environment where people live. However, urban regulation depends on an uncertain future, which always involves risk and depends on the factors characterising the people living there. On the other hand, urban planning is a political activity and is not always based on research, but rather on people's needs (Eliasson, 2000). Planners' conceptions include "more abstract ideas of the perception ... of place" (Ganis, 2009: 47). Harold Proshansky (1972), Abraham Wandersman (1976) and John Douglas Porteous (1977) highlighted the discrepancies between residents' and planners' views as early as the 1970s. In addition, Nataša Bratina (1997), Barbara Goličnik (2005), Michèle Jole (2008), Jane Jacobs (2009) and Igor Bizjak (2012) state that, despite the vital relevance of this relationship, planners continue to neglect users' role and opinions. Based on their research, they note that " $[\mathrm{t}]$ he views and positions of planners and users may vary greatly" (Jurkovič, 2014: 108). Urban planners' social constructs influence the perception of how and what kind of space should be produced. "The psychological aspect is related to the direct experience and perception of a space, whereas the structural aspect shows that public urban spaces are an important spatial category in the urban structure" (Jurkovič, 2014: 111). Space and ideology have a tense and dialectical relationship - the latter tries to mould the former, but it finds itself affected by the very space that it seeks to change (Bourdieu, 2001).

By observing the factors characteristic of a particular nation whose space one wants to regulate, it is possible to categorise urban planning patterns based on national identity, ethnic nationalism, social constructs and political pressure. This study examines urban planners' perceptions, and it clarifies the structural relationship between the four factors and urban planners' perceptions and intentions to regulate space in a particular way. Based on a literature review, the four factors are the following: 1) national identity, 2) ethnic nationalism, 3) social constructs and 4) political pressure. The study also has practical implications that can help real estate developers examine the relative importance of these factors on urban planners' perceptions and intentions, allowing them to predict future investments.

First, national identity is the most salient cultural factor that can influence urban planners' perceptions and intentions. There is a direct relationship between urban planning and evolving conceptions of national identity (Neill, 2004). Second, nationalism is an important parameter that shapes modern urban planning. Through nationalism, people may identify strongly with a particular community known as a nation - which may or may not correspond to one or more coun- tries. This is sometimes further complicated by the fact that individuals identifying with the same nation may nevertheless hold differing senses about what that national identity signifies. People that identify with a particular community look around them to find expressions of their national and civic identities in that community, and generations both consciously and unconsciously express their identities in the material culture of brick, stone, marble and concrete, just as they do in literature and art. Third, in our view, Lefebvre's theory of space has a relatively high degree of affinity with more recent trends in social construction that consider the reality of an object. For instance, "spatial practice" is a process that represents rational conceptions of the "representation of space" through physical mediations such as buildings and monuments and serves as a reference point for coordinating action with thinking. The space that is produced is composed of a series of conventions. Moreover, the space itself could be considered a convention. Finally, Lefebvre's theory of space further states that spaces are produced because of particular political interests. According Lefebvre's theory, the production of space as the construction of a specific reality usually takes place based on a political process around a specific normative value that allows the qualification of people and objects (things). In our view, urban planners try to change the urban infrastructure into a new built environment adequate for the "representation of space". Their intentions are driven by endogenous socio-economic dynamics and political pressures. "Urban planning as an overarching discourse is seriously challenged by the politics and pressures of political elites" (Newman, 2000: 8).

We use a qualitative method to address the complex situation of urban planners' perceptions on regulating space. We used purposive sampling to select our respondents and used semistructured interviews in cross-case analysis to determine how national identity, ethnic nationalism, social constructs and political pressure affect the way planners perceive space and, based on those perceptions, how they construct their intentions. The first part of this article reviews the literature and constructs hypotheses based on this. The second part presents the qualitative research used, the research subjects and purposive sampling used, the protocol for the qualitative interviews and the findings of the empirical research.

\section{Theory background and constructing the hypotheses}

In general, there is a direct relationship between urban planning and evolving conceptions of national identity (Neill, 2004). Mel Ravitz (1988) states that basic cultural and social forces, including national identity, affect planners' perceptions. Tim Edensor (2002) states that national identity also can be 
represented through what he calls iconic "sites". He further states that " $[\mathrm{t}]$ he spatial symbols that connote historical events are evidence of past cultures, providing evidence of a glorious past of golden age and antecedence" (Edensor, 2002: 45). According to Laura Kolbe (2007), in many post-communist eastern European capital cities, the countries were committed to producing space that would create an image denoting the resurgence of the nations' previously oppressed cultural development. It is noteworthy that a capital city's central district, packed with global retailers, international entertainment venues and skyscrapers, can also be a physical representation of the nation's economic achievement alongside modernisation. Kolbe (2007) further states that many post-communist countries in eastern Europe began setting up new business districts in the capital cities to create the new images of the nation as well as to boost the domestic economy. New official buildings, combining western and traditional architectural styles, could be erected to symbolise the nation's independence as well as its ability to pursue modernisation (Vale, 2006). Individuals from different ethnic groups can present their cultural symbols or activities in a city's public places, such as parks or squares (Rishbeth, 2004). In this space an ethnic group can freely maintain its cultural practices as well as its identity. Hypothesis 1 is based on the literature reviewed: If urban planners work during a nation-building phase, then their perceptions will reflect more elements of national identity.

In terms of the link between the ethnic nationalism and urban planning, the ethnic and nationalist elements of urban planning are manifested in land policies, settlement systems, municipal and regional boundaries, and cultural landscapes as part of an ethnocratic planning regime that aims to further the goals of a dominant ethnic group while using a crude rhetoric of "democratic" majoritarian rule (Yiftachel, 2004). Eoghan Harris (2003) states that this is a never-ending struggle for ethnicising space as part of a planning theory, and hence as making the nation-state dynamic and internal to the planning endeavour, and not a "flat" and unexplored "given", which is particularly the case for "homeland" ethnic groups. Hastings Donnan (2005: 78) provides an example of how " $t \mathrm{t}$ he the minority Irish Protestant community engages in the practice of ethnicizing space by constructing narratives of dispossession". On the other hand, Lewis Mumford (1961: 562) observes that "the historic city retains, by reason of its amplitude and its long past, a larger and more various collection of cultural specimens than can be found elsewhere". In addition, David Harvey (2001) notes that the city centre is a great book of time and history, and that different identities and contending conceptions of the same identity hold different narratives, and look to promote recognition of those narratives in the city spaces around them. The connection between nationalism and urbanism is recorded in the works of Juval Portugali (2000).
Nationalism is the driving force that determines the hierarchical authority that determines who should live and work in the city and where and how (Portugali, 2000). Regarding the link between ethnic nationalism and urban planning, Mirjana Rističs (2011) study of the post-war reconstruction of Sarajevo shows that the ethnic conflict shifted to the production of ethnic symbolism through re-inscription and memorialisation. In another article linking nationalism and urban planning, Muna Güvenç (2011) states that Kurdish nationalism in Diyarbakır, Turkey is being built through the urban experience of collectivism in diverse socio-spatial and political encounters, rather than solely through top-down interventions. Hypothesis 2 is based on the literature reviewed: If urban planners engage in post-war urban planning or urban planning in a nation with a history of oppression or conflict, then their perceptions will reflect greater ethnic nationalist elements.

On the other hand, the social construction of space is perceived as "the actual transformation of space through social exchanges, memories, images, and daily use of the material setting into scenes and actions that convey symbolic meaning" (Low, 1996: 862). Manuel de Solà Morales states that urbanism necessarily entails the application of ideas to different realities. De Sola Morales sees urbanism as a social construct. "The social construction of reality is marked by a continuous redesign of urban symbols" (Iwata \& Del Rio, 2004: 171). The sensed world is a representation of reality that results "from options and decisions about what to represent" (Castro, 2000: 12). According to Setha M. Low (1996), a relationship may be established between the circumstances of the production of public spaces and people's perceptions of them. Although historical, sociopolitical, economic and professional understandings are issues belonging to social production of space, social use and emotional meanings pertain to social construction of space (Richardson, 1982). Henri Lefebvre (1991: 286) states that "space is not only supported by social relations but it is also produced by social relations". The social construction of space, which is created by mediated social exchanges, affects planners' perceptions. Hypothesis 3 is based on the literature reviewed: If urban planners engage in more mediated social exchanges, then their perceptions on regulating space reflect a greater level of emotional meanings and social constructs.

Planners' perceptions are often influenced by pressures from political elites. These pressures are created through the power struggles by these elites to produce space. There is a direct relationship between planners' perceptions and political pressure (Sennet, 1990). Michel Foucault (1984) examines the relationship of power and space by positing architecture as a political technology for working out the concerns of government - that is, control and power over individuals - through the spatial canalisation of everyday life (Foucault, 1984). Peter Newman 
(2000) states that city planning strategies are shaped by degrees of power and different interests. This implies that the face of the city is moulded by the social ideologies of those that have the power to sculpt it. Simultaneously, "space can become a visible articulation of the conflict between divergent ideologies and their struggles for the authority to concretise these frameworks, to sculpt their physical surroundings" (Appadurai, 2000: 648). Thus, the relationship between space and ideology is negotiated, like any other. Powerful institutions such as the state may impose certain views on spaces and structures, and its ideology engages in a constant cycle of revision and transformation, meted out through negotiations among the various actors involved. Allen Scott (2014) emphasizes that, as a consequence of power struggles between various elites, cities suffer from spatial disparities due to disparities between classes. Hypothesis 4 is based on the literature reviewed: If urban planners work under a major power struggle of political elites, then their perceptions on regulating space reflect more elements of political identity.

According to Howard Robinson (1994: 2) "intentionality is the property of states of being about things". An ordinary physical state is not about anything, it is simply there, unless it is interpreted as being about something. However, thoughts, beliefs, desires, and most mental attitudes are essentially about things. They refer beyond themselves and they are directed upon objects. According to William J. V. Neill, most theories concentrate on planners rather than on planning. Planning stands for the broader arena of publicly guided transformation of space (Yiftachel, 2004). Neill (2004) further states that planners' desires play a significant role in creating a common meaning among difference. Ravitz states that planners' intentions to regulate space in a particular way are not affected by their conceptions of space, but instead by the attitudes of the middle-class majority (1988, cited in Thomas, 1997). Roisin Higgins (2001: 29) states that urban planners' intentions can be either political or historical. Planners' conceptions range from "the more abstract ideas of the perception and experience of place to contemporaneous planning practices of more concrete urban infrastructure such as buildings, services and movement systems" (Ganis, 2009: 47). Further, such conceptions are also driven by the "small world paradigm" of small clusters of habitats (Ganis, 2009). As Ingegärd Eliasson (2000) states, planning is a political activity and is not always based on research, but instead on people's needs. Hypothesis 5 is based on the literature reviewed: The greater planners' perceptions are when regulating space in a certain way, the greater are their intentions to produce space in that way.

\section{Research method}

We used a qualitative research method to explore complex situations in urban planning that cannot be easily quantified. A qualitative research approach allows us to answer our research questions. This method can provide intricate details of phenomena that cannot be derived through quantitative methods (Strauss \& Corbin, 1990). The qualitative technique is a more intrusive technique and is less structured than a quantitative method, allowing the interviewer to gain insight into the topic studied (Jarrratt, 1996). We used a semi-structured interview for this research interest. We used a smaller sample of participants for the interviews. However, because this is a qualitative research technique, the data cannot be quantified.

\subsection{Research subjects and samples}

We used purposive sampling as a non-probability sampling technique for qualitative interviews. We selected the respondents based on our judgment, and the selection of respondents had to conform to certain respondent criteria (Cooper \& Schnidler, 2001). The power of purposive sampling lies in the proper selection of respondents that have plentiful information about urban planning and planners' perceptions.

This research examines the impact of cultural factors in planners' perceptions and the impact of planners' perceptions on their intentions to regulate space in a certain way. Consequently, the sample mainly included planners employed by the Municipal Urban Planning Department of Prishtina and the Institute of Urban Planning at the Ministry of the Environment and Spatial Planning of the Republic of Kosovo that worked during the period from 1999 to 2014 and experienced post-war reconstruction in Kosovo. Four important criteria for selecting the sample were: a) at least ten years of practical experience in urban planning, b) involvement in planning certain public places in Prishtina, c) experience of the Kosovo war from 1998 to 1999 and d) urban planning work under various municipal and central governments. The types of respondents, their codes and their characteristics are presented in Table 1.

\subsection{Protocol for qualitative interview}

The qualitative research method provides for a set of various data collection techniques such as interviews, focus group interviews and observation (Luna Reyes \& Andersen, 2003). In this study we use in-depth semi-structured interviews that follow the research protocol created especially for this study. This protocol includes questions related to the research issue, and these lead to follow-up questions. The protocol was pretested 
Table 1: Types of respondents, codes and characteristics

\begin{tabular}{lll}
\hline Respondent type & Code & Characteristics \\
\hline Only municipal planners & $\mathrm{PL}_{1}$ & Ten years of experience; worked in Prishtina immediately after the war \\
\hline Municipal and central planners & $\mathrm{PL}_{2}$ & $\begin{array}{l}\text { Ten years of experience; worked in Prishtina and also for the Ministry of the Enviro- } \\
\text { nment }\end{array}$ \\
\hline Planners exposed to war & $\mathrm{PL}_{3}$ & Ten years of experience; exposed to the war in Kosovo from 1998 to 1999. \\
\hline Planners under various governments & $\mathrm{PL}_{4}$ & Ten years of experience; worked under various municipal and central governments \\
\hline
\end{tabular}

Table 2: Respondents, experience, employers and jobs

\begin{tabular}{llll}
\hline $\begin{array}{l}\text { Respon- } \\
\text { dents }\end{array}$ & $\begin{array}{l}\text { Experience } \\
\text { (years) }\end{array}$ & Employer & Job \\
\hline C1 & 10 & Municipal department & Head \\
\hline C2 & 12 & Ministry & Senior planner \\
\hline C3 & 10 & Ministry & Planner \\
\hline C4 & 13 & Ministry & Senior planner \\
\hline C5 & 14 & Municipal department & Senior planner \\
\hline C6 & 13 & Municipal department & Senior planner \\
\hline C7 & 10 & Ministry & Planner \\
\hline C8 & 10 & Ministry & Director \\
\hline C9 & 13 & Municipal department & Senior planner \\
\hline C10 & 12 & Municipal department & Planner \\
\hline C11 & 11 & Ministry & Planner \\
\hline C12 & 13 & Municipal department & Planner \\
\hline
\end{tabular}

Table 3: Categorisation of cases

\begin{tabular}{|c|c|c|}
\hline $\begin{array}{l}\text { Category } \\
\text { code }\end{array}$ & Category description & $\begin{array}{l}\text { Case identification } \\
\text { code }\end{array}$ \\
\hline $\mathrm{PL}_{1}$ & Only municipal planners & $\mathrm{C} 1, \mathrm{C} 5, \mathrm{C} 12$ \\
\hline $\mathrm{PL}_{2}$ & Municipal and central planners & $\mathrm{C} 2, \mathrm{C} 4, \mathrm{C} 10$ \\
\hline $\mathrm{PL}_{3}$ & Planners exposed to war & $\mathrm{C} 3, \mathrm{C} 6, \mathrm{C} 8$ \\
\hline $\mathrm{PL}_{4}$ & $\begin{array}{l}\text { Planners under various gover- } \\
\text { nments }\end{array}$ & $\mathrm{C} 7, \mathrm{C} 9, \mathrm{C} 11$ \\
\hline
\end{tabular}

with one urban planner from the Institute of Urban Planning of the Ministry of Environment. The qualitative data were collected from urban planners that are fluent in English, and so translation of the interview protocol was not required for this study. A semi-structured questionnaire accompanied by a voice recorder were used as research instruments in collecting the qualitative data. The research instrument included derived constructs that link national identity, nationalism, social constructs and political pressure with planners' perceptions and ultimately with their intentions. The questionnaire allowed respondents to tell stories about constructs linked with the planners' perceptions and to seek examples in Prishtina.

\subsection{Qualitative data analysis}

Each urban planner interviewed was as a respondent unit, or single case. In this study we also conducted a cross-case analysis to see whether there is any comparison or contrast between cases. Chad Perry (1998) suggests that a descriptive evaluation of each source of information should be performed. In this case analysis, the descriptive evaluation is a descriptive statistical analysis in quantitative research. No single standard approach is suggested for analysing qualitative information. As highlighted above, we use cross-case analysis. For better crosscase analysis, we coded the data into several categories to facilitate comparison and contrast between cases. We grouped the respondents into four main categories termed $\mathrm{PL}_{1}$ to $\mathrm{PL}_{4}$, as illustrated in Table 1, based on the whether they were exposed to post-war Prishtina, whether they worked for the municipal or central government and whether they were exposed to different governments ruled by various political parties. Based on the criteria of selecting knowledgeable respondents for indepth interviews, respondents belonging to each category were selected. As a result, twelve planners were identified: three in each category. Among these, nine interviews were recorded. Three respondents were reluctant to have their interviews recorded and these preferences were noted on the interview protocol sheet. Each of the interviews took about 40 minutes. The respondents' profiles are shown in Table 2.

To ensure the richness of the qualitative data, Table 2 separately shows each respondent's years of experience, current place of employment and current job. The cases are categorised by the category codes in Table 3. The research first focused on cultural factors before examining the constitutive elements of the research model (Figure 1).

\section{Qualitative research findings}

This section presents the findings and cross-case views of the interviewees based on comments from key respondents. The cross-case analysis of each construct integrated in the conceptual model presented above provides a strong basis for understanding the key issues involved in this study. The qualitative study explores the strength of influence of each of the cultural factors in the conceptual framework on planners' perceptions and then explores the strength of influence of planners' perceptions on their intentions. The influence factors and their strength are discussed below based on the cross-case analysis and tables developed. We then establish the relationship 


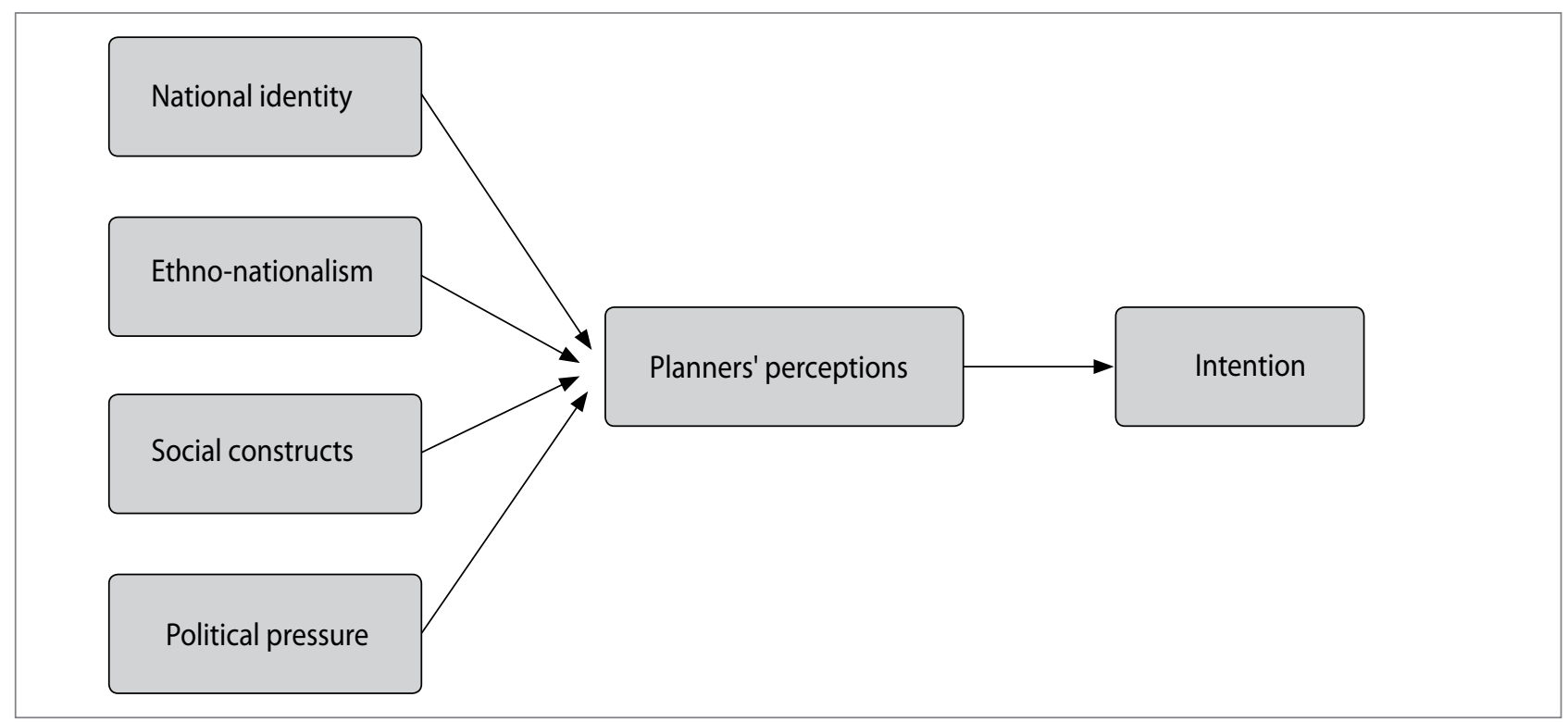

Figure 1: Research model

between each influence factor and planners' perceptions, and between planners' perceptions and planners' intentions.

\subsection{National identity and planners' perceptions}

National identity was identified as a significant driver of planners' perceptions in post-war Prishtina. Some respondents ( $\mathrm{Cl}$ and C5) emphasised that national identity and cultural identity are different. They stated that national identity is a collective identity that is created during a nation-building stage regardless of ethnicity, religion and regional affiliation, whereas cultural identity is an identity that various sub-cultures within a nation state create. $\mathrm{C} 1$ stated:

Yes, I do agree that national identity is different from cultural identity. Cultural identity is expressed in the form of various subcultures that various groups of populations create geographically and regionally in Kosovo. For instance, citizens of Prishtina are different and have different cultural expressions than citizens of other cities in Kosovo. City of Prishtina, culturally is like a mixture of many mini-cultures coming from other geographical regions of Kosovo, including the international presence in Kosovo highly concentrated in Pristhina. As Kosovo is in the stage of nation-building, all the subcultures are struggling to create a new Kosovar identity as opposed to Albanian identity. And this post-war Kosovar identity has influenced significantly on urban planners to regulate various public spaces in Prishtina in the way that would express the identity of newly born country with doses of Albanian ethnic nationalism. All these are expressed in the new squares built in Prishtina after the war such as Skenderbeg Square, Zahir Pajaziti Square, Ibrahim Rugova Square, including the Bill Clinton Square. Even the Bill Clinton Square in my opinion expresses the new Kosovar national identity because Bill Clinton is considered to have significantly helped in the creation of independent Kosovo. The refurbishment of Mother Theresa street and refurbishment of the eldest hotel in the city of Prishtina Hotel Union dating from the beginning of $19^{\text {th }}$ century and its conversion into a Benetton shopping mall exhibits combination of modernism and traditionalist architecture and is an element of new Kosovar national identity. The refurbishment of Kosovo Government building, the building of several roundabouts in the exits of Prishtina show that the planner's perception was influenced by the sense of national identity in the making, because the planners not only wanted to solve the traffic problems of citizens of Prishtina but wanted to show the economic strength of the newly independent country of Kosovo. [sic]

This statement shows an important aspect of how national identity affects urban planning in general and planners' perceptions when regulating public space to express national identity elements. Nevertheless, the interviewees revealed a complex situation in which some of the findings confirmed the hypotheses in this study and some others challenged the impact of national identity on planners' perceptions and how planners' perceptions are influenced by their urban planning experience during the nation-building phase. Skenderbeg Square, Zahir Pajaziti Square, Ibrahim Rugova Square, Bill Clinton Boulevard, Prishtina Hotel Union and the Kosovo Government Building are shown in Figures 2-7.

Table 4 shows how national identity affects planners' perceptions. Group 1 contains respondents that perceived a direct effect of national identity on perceptions, and in Group 3 there was no direct effect of national identity on perceptions, but instead a reverse effect of perceptions on national identity. In Group 4, national identity had no impact on perceptions.

Section 2 suggested that if urban planners worked during the nation-building phase then their perceptions would reflect 


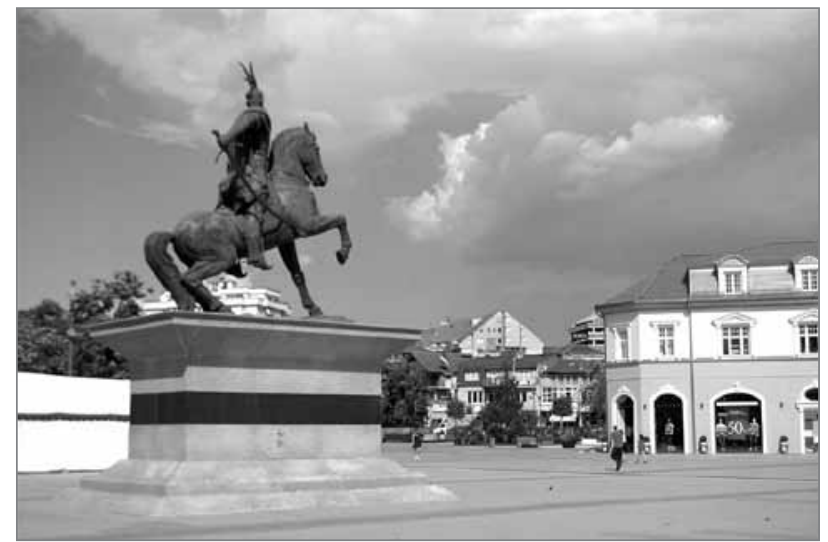

Figure 2: Skenderbeg Square (photo: Arben Asllani).

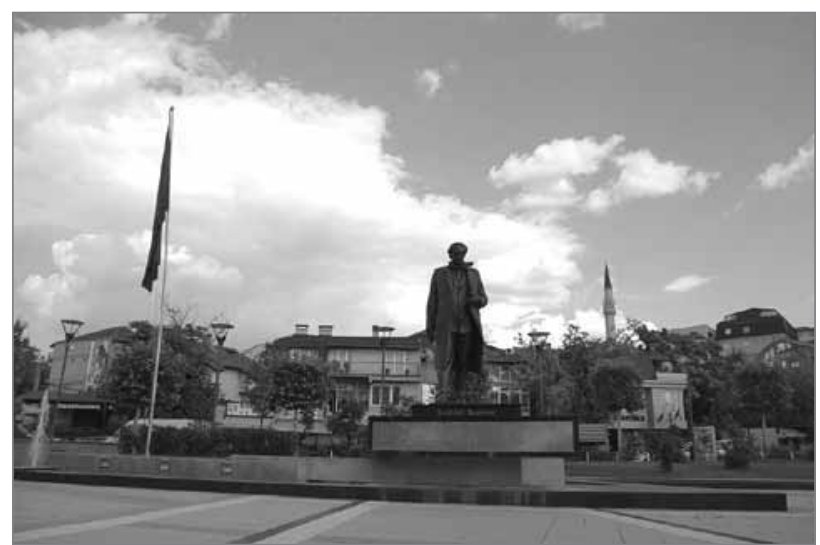

Figure 4: Ibrahim Rugova Square (photo: Arben Asllani).

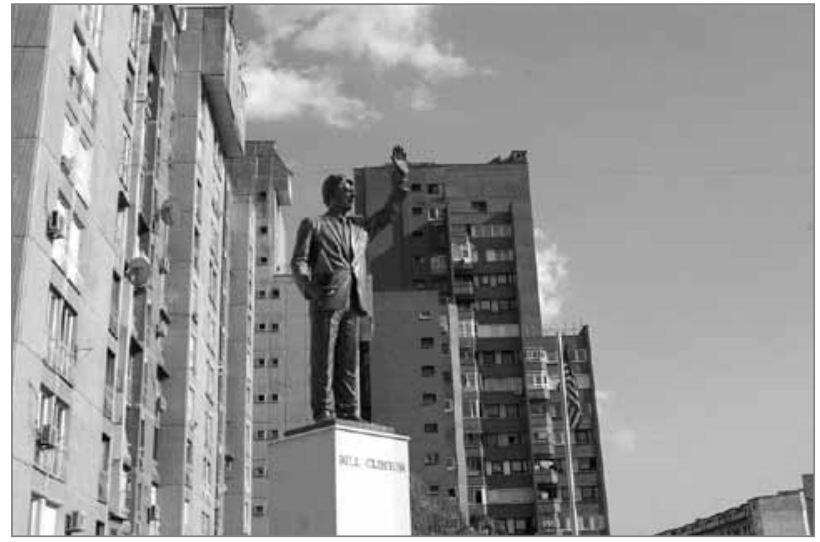

Figure 5: Bill Clinton Boulevard (photo: Arben Asllani).

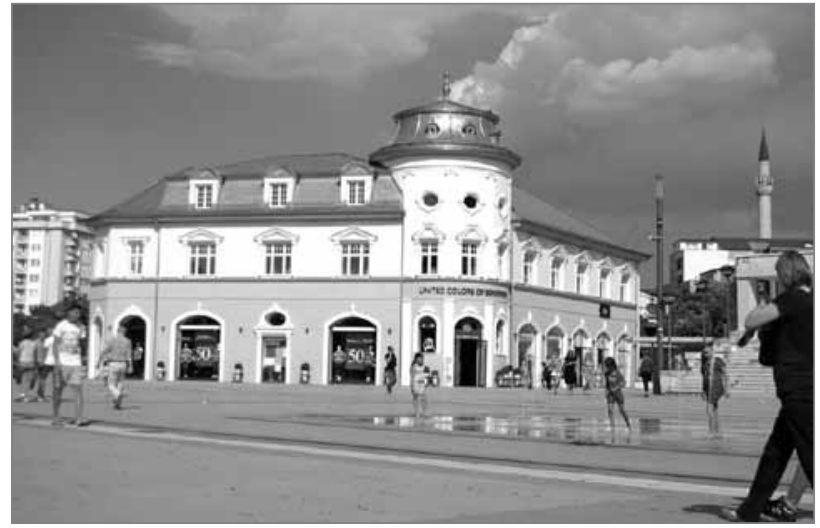

Figure 6: Prishtina Hotel Union (photo: Arben Asllani).

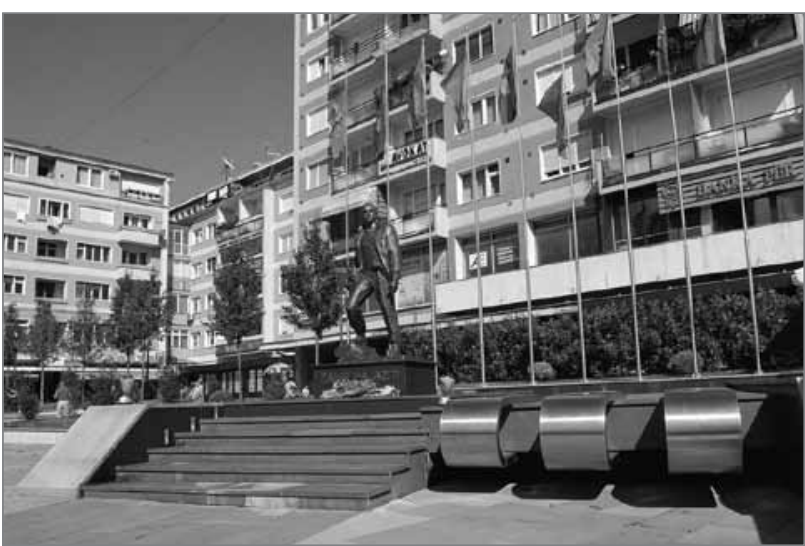

Figure 3: Zahir Pajaziti Square (photo: Arben Asllani).

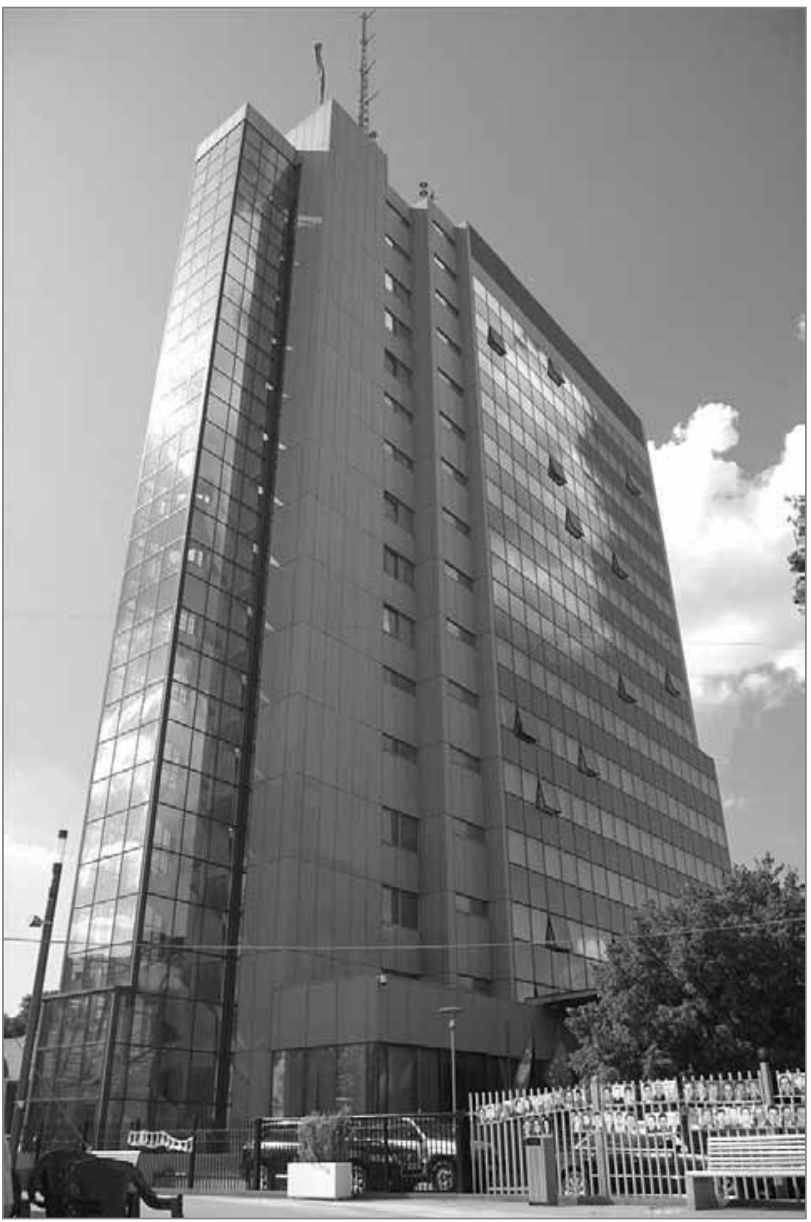

Figure 7: Kosovo Government Building (photo: Arben Asllani).

greater national identity elements. Table 4 shows that the six respondents in Group 1 appear to validate the theoretical expectation, as stated by Neill (2004) and Ravitz (1988). This study shows that half of respondents felt that national identity had a significant impact on planners' perceptions in Prishtina. On the other hand, one-fourth of them acknowledged that planners' perceptions can shape national identity through the public spaces they create. 
Table 4: National identity and planners' perception

\begin{tabular}{ll}
\hline & Planners' perception \\
\hline & 1. Direct positive effect \\
& C1, C5, C6, C8, C10, C11 \\
\hline 2. Moderate effect \\
\cline { 2 - 2 } National identity & $\begin{array}{l}\text { 3. Reverse effect } \\
\text { C2, C4, C12 }\end{array}$ \\
& 4. No effect \\
C3, C7, C9
\end{tabular}

\subsection{Ethnic nationalism and planners' perceptions}

Table 5 shows the effects of ethnic nationalism on planners' perceptions. Similar to Table 4, Groups 1, 2, 3 and 4 show the effect of nationalism on planners' perceptions in Prishtina. The respondents were divided into three categories; only onefourth confirmed the hypothesis, and half did not.

In particular, $\mathrm{C} 2$ confirmed the hypothesis that nationalism affects planners' perceptions so that they include nationalistic elements when regulating space. $\mathrm{C} 2$ stated:

The building of Skenderbeg square after the war just in the front of the Government Building of Kosovo bearing in mind that Skenderbeg is the most famous Albanian national hero, explicitly states that the planners had in mind to show ethnic elements of Albanians and the glory he represents. On the other hand, the building of Zahir Pajaziti square in the center of Prishtina, explicitly states that the planners were driven mainly by the nationalistic sentiment that they had after the war, with which they wanted to express revolt against what happened in the war. Zahir Pajaziti is the first commander of Kosovo Liberation Army and representing him in the center of Prishtina in my view is nothing but a nationalistic expression of planners. This nationalistic expression of planners originates even from the planning decision-makers of Prishtina who during the eighties decided to build cone hats of Albanians on the top of National Library of Kosovo. We all know that cone hats are a pure Albanian nationalistic expression. Even during the communism when Kosovo was in Socialist Federal Republic of Yugoslavia, we had the attempts from the planning decision-makers at that time to exhibit elements of Albanian nationalism. [sic]

The National Library of Kosovo is shown in Figure 8. C8 states the opposite of $\mathrm{C} 2$, commenting that planners were more driven by the struggle between political elites after the war, who wanted to portray figures that represented their line of thinking. C8 stated:

I do not think that the planners of Prishtina were driven by nationalistic element when they planned the Square of Zahir Pajaziti, Square
Table 5: Ethnic nationalism and planners' perception

\begin{tabular}{|c|c|}
\hline & Planners' perception \\
\hline \multirow{7}{*}{ Nationalism } & 1. Direct positive effect \\
\hline & $\mathrm{C} 2, \mathrm{C} 4, \mathrm{C} 6$ \\
\hline & 2. Moderate effect \\
\hline & $\mathrm{C} 1, \mathrm{C} 5, \mathrm{C} 7$ \\
\hline & 3. Reverse effect \\
\hline & 4. No effect \\
\hline & $\mathrm{C} 3, \mathrm{C} 8, \mathrm{C} 9, \mathrm{C} 10, \mathrm{C} 11, \mathrm{C} 12$ \\
\hline
\end{tabular}

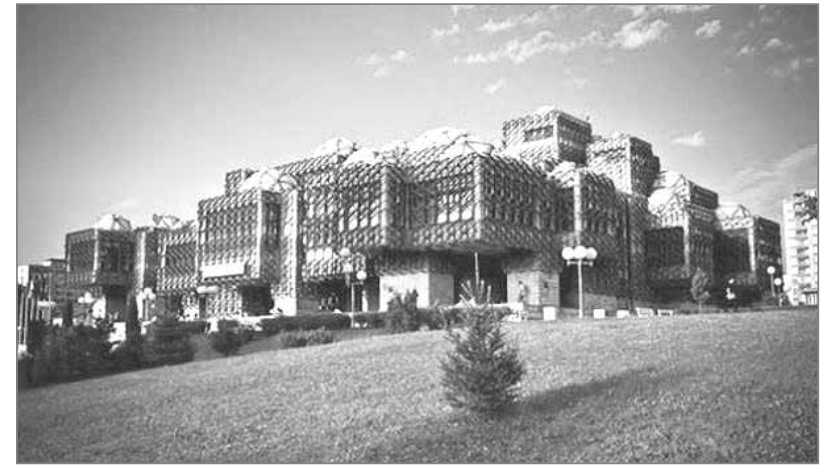

Figure 8: National Library of Kosovo (photo: Arben Asllani).

of Bill Clinton or Square of Ibrahim Rugova. Ibrahim Rugova represents the pacifist line of Kosovo Albanians and not the nationalistic line. The planning of these squares were more the struggle between two main political parties Kosovo Democratic Party representing the war wing of Kosovar society and Kosovo Democratic League representing the pacifist line. They were in struggle between each other after the war and each of them influenced on planners to produce these spaces, which represented their party heroes. For instance Bill Clinton Boulevard was not made to exhibit nationalist elements of Albanians against Kosovo Serb population but because both main political parties wanted to be servile towards United States government. Also, the Catholic Cathedral built in the center does not show any nationalistic element. It was not even produced as a space because of religious element. It was produced because political elites wanted to show to the Western countries that despite of the fact that Kosovo Albanians are predominantly Muslim, they affiliate themselves more with modern values of Western societies. [sic]

\subsection{Social constructs and planners' perceptions}

Table 6 shows the effects of social constructs on planners' perceptions. Similar to Tables 4 and 5, Groups 1, 2, 3 and 4 specify the extent to which social constructs affect planners' perceptions in Prishtina. The key respondents were divided into three groups, whereby only one-sixth confirmed the hypothesis, and two-thirds of respondents did not. 
Table 6: Social construct and planners' perception

\begin{tabular}{ll}
\hline \multicolumn{1}{c}{ Planners' perception } \\
\hline & $\begin{array}{l}\text { 1. Direct positive effect } \\
\text { C3, C4 }\end{array}$ \\
\cline { 2 - 2 } 2. Moderate effect \\
& C1, C9 \\
\cline { 2 - 2 } & 3. Reverse effect \\
\cline { 2 - 2 } & 4. No effect \\
& C2, C5, C6, C7, C8, C10, C11, C12 \\
\hline
\end{tabular}

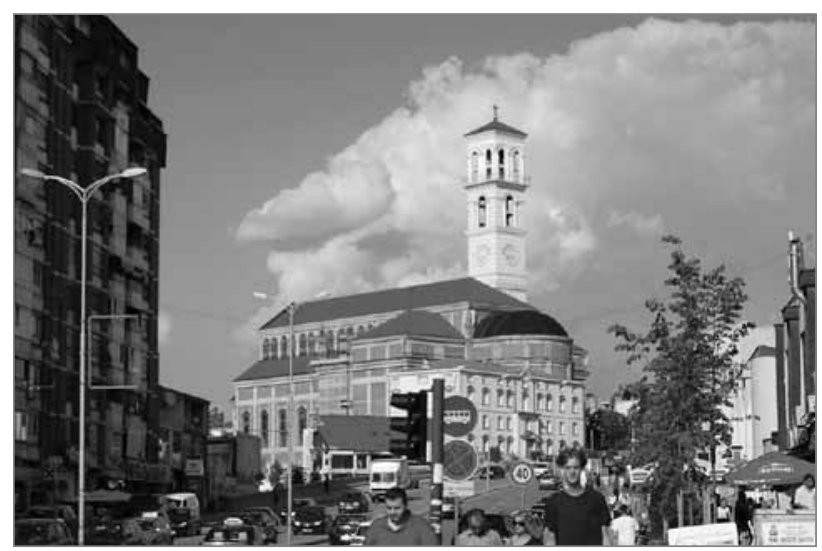

Figure 9: Catholic Cathedral (photo: Arben Asllani).

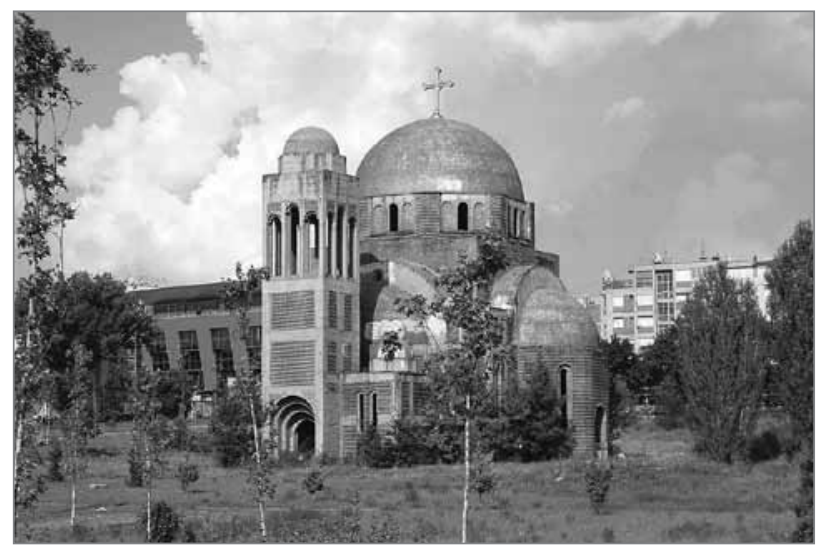

Figure 10: Orthodox Church (photo: Arben Asllani).

C3 agreed with the hypothesis and stated:

I agree that if the planner is engaged in social mediated processes with people they give symbolism to things and spaces. We give symbolism to things. By producing these spaces, the planners of Prishtina who were involved in that gave symbolism to those squares and the symbolism was that Kosovo Albanians are heroes and that they fought the war and won the war. For instance, the Serbs built the monument of Gazimestan because they like to give symbolism to the defeat that they had in the Battle of Kosovo with Otoman Empire. Furthermore, you can notice the newly built cathedral in the center of Pristhtina, which confirms that our national identity
Table 7: Political pressure and planners' perception

\begin{tabular}{|c|c|}
\hline & Planners' perception \\
\hline \multirow{6}{*}{ Political pressure } & 1. Direct positive effect \\
\hline & $\mathrm{C} 1, \mathrm{C} 3, \mathrm{C} 5, \mathrm{C} 7, \mathrm{C} 8, \mathrm{C} 9, \mathrm{C} 10, \mathrm{C} 11, \mathrm{C} 12$ \\
\hline & 2. Moderate effect \\
\hline & 3. Reverse effect \\
\hline & 4. No effect \\
\hline & $\mathrm{C} 2, \mathrm{C} 4, \mathrm{C} 6$ \\
\hline
\end{tabular}

has been socially constructed even before the war - as a society of interfaith tolerance where all three major religions coexist peacefully in Kosovo, but more so in Prishtina. Prishtina is a home to the newly built catholic cathedral, muslim mosque, and orthodox church. [sic]

The Catholic Cathedral and Orthodox Church are shown in Figures 9 and 10. In contrast to C3, C5 stated:

I do not think that the planner is influenced by the social mediated processes. In the end of the day, it is the policy-makers who decide what to produce as a space and planners only implement their decisions and their perception. The social constructionism created about the space and surrounding does not have the leading role in deciding what kind of space to produce and what that space should symbolise. [sic]

\subsection{Political pressure and planners' perceptions}

Table 7 shows the effects of political pressure on planners' perceptions. Similar to the previous tables, Groups 1, 2, 3 and 4 specify the level of perception regarding the effect of political pressure on planners' perceptions in Prishtina. The key respondents were divided into three groups; only three-fourths confirmed the hypothesis and one-fourth did not.

C5 states that political pressure has the most effect on planners' perceptions. C5 stated:

It is the political pressure that has the highest effect on the planner's perception about regulating space. It was only the Square Skenderbeg that both main political parties PDK and LDK had an agreement. The Square of Zahir Pajaziti was the square that was suggested by PDK to represent the war wing. On the other hand, the LDK party representing the pacifist side of the war suggested the Ibrahim Rugova square to counterbalance the struggle for production of space that would represent elements of their political thinking. Even the Cathedral that was built in the center of Prishtina was suggested by the late President Ibrahim Rugova who was in good terms with the Vatican and the Pope John Paul II. [sic] 
Table 8: Planners' intentions and planners' perception

\begin{tabular}{|c|c|}
\hline & Planners' perception \\
\hline \multirow{7}{*}{ Planners' intentions } & 1. Direct positive effect \\
\hline & $\mathrm{C} 1, \mathrm{C} 2, \mathrm{C} 4, \mathrm{C} 7, \mathrm{C} 8, \mathrm{C} 9, \mathrm{C} 10, \mathrm{C} 11$ \\
\hline & 2. Moderate effect \\
\hline & $\mathrm{C} 3, \mathrm{C} 5, \mathrm{C} 12$ \\
\hline & 3. Reverse effect \\
\hline & 4. No effect \\
\hline & $\mathrm{C} 2, \mathrm{C} 4, \mathrm{C} 6$ \\
\hline
\end{tabular}

\subsection{Planners' perceptions and planners' intentions}

Table 8 shows the effects of planners' perceptions on their intentions. Similar to the previous tables, Groups 1, 2, 3 and 4 show how planners feel their perceptions affect their intentions. The respondents were divided into three groups; twothirds confirmed the hypothesis, and one-third did so partially. Table 9 summarises the cross-case analysis based on codes. Based on the qualitative analysis, the research model shown in Figure 11 is further validated by the cross-case analysis.

\section{Discussion}

Hypothesis 1, "If urban planners work during a nation-building phase, then their perceptions will reflect more elements of national identity", seems to be supported by half of respondents in the cross-case qualitative analysis, whereas one-fourth of respondents acknowledged that planners' perceptions can have a reverse effect on national identity through the public spaces that they create. Breda Mihelič (2008) explains that Fabiani's work as an urban planner of cities such as Ljubljana and various Italian and Austrian towns was influenced by his sense for the local environment and respect for the local spirit and belonging to the place. Mihelič (2008: 129) also states that planners' perception that they should regulate space according to a feeling of belonging and identification with cultural elements and the national narrative can be noted in culturalist cities, which have no trace of geometry or prototype forms and the only thing that they emphasise is the "notion of a community and a sense of collective spirit". Francisca Márquez (2011) states that identities are a field of conflict and they depend on a sincere recognition of otherness to grant them recognition and legitimacy, and that meanings of identity are reflected through intentions in concrete contexts. Even in sites considered to be of little interest, people's historical and cultural identity has catalysed planners' attention. This was the case with setting up the master plan for Atlanta's public transit system (Gilberti, 2013). On the other hand, telephone booths or streetlamps, despite the fact they are basic furnishings of any urban space, also represent the accent of a place; they are a symbol that facilitates identification and national identity (Banach-Ziaja, 2008). Roberto Rocco (2003) studies the emergence of neoclassical style buildings in São Paulo, which he says are a consequence of the crisis of national identity in Brazil.

Table 9: Summary report of cross-case analysis

\begin{tabular}{|c|c|c|c|c|c|c|c|}
\hline \multicolumn{3}{|c|}{ Variables and paths } & \multirow{2}{*}{$\frac{\text { Code } \mathrm{PL}_{1}}{\mathrm{C} 1, \mathrm{C} 5}$} & \multirow{2}{*}{$\frac{\text { Code } \mathrm{PL}_{2}}{\mathrm{C} 10}$} & \multirow{2}{*}{$\frac{\text { Code } \mathrm{PL}_{3}}{\mathrm{C} 6, \mathrm{C} 8}$} & \multirow{2}{*}{$\frac{\text { Code } \mathrm{PL}_{4}}{\mathrm{C} 11}$} & \multirow{2}{*}{$\begin{array}{l}\text { Comment } \\
\text { Expected }\end{array}$} \\
\hline NATID & $\rightarrow$ & PER & & & & & \\
\hline ETNAT & $\rightarrow$ & PER & & $\mathrm{C} 2, \mathrm{C} 4$ & C6 & & Not expected \\
\hline SOCCON & $\rightarrow$ & PER & & C4 & C3 & & Not expected \\
\hline POLPRES & $\rightarrow$ & PER & $\mathrm{C} 1, \mathrm{C} 5, \mathrm{C} 12$ & $\mathrm{C} 10$ & $\mathrm{C} 3, \mathrm{C} 8$ & $\mathrm{C} 7, \mathrm{C} 9, \mathrm{C} 11$ & Expected \\
\hline PER & $\rightarrow$ & INT & $\mathrm{C} 1$ & $\mathrm{C} 2, \mathrm{C} 4, \mathrm{C} 10$ & C8 & $\mathrm{C} 7, \mathrm{C} 9, \mathrm{C} 11$ & Expected \\
\hline
\end{tabular}

Note: NATID = national identity, ETNAT = ethnic nationalism, SOCCON = social constructs, POLPRES = political pressure, PER = planners' perceptions, INT = planners' intentions

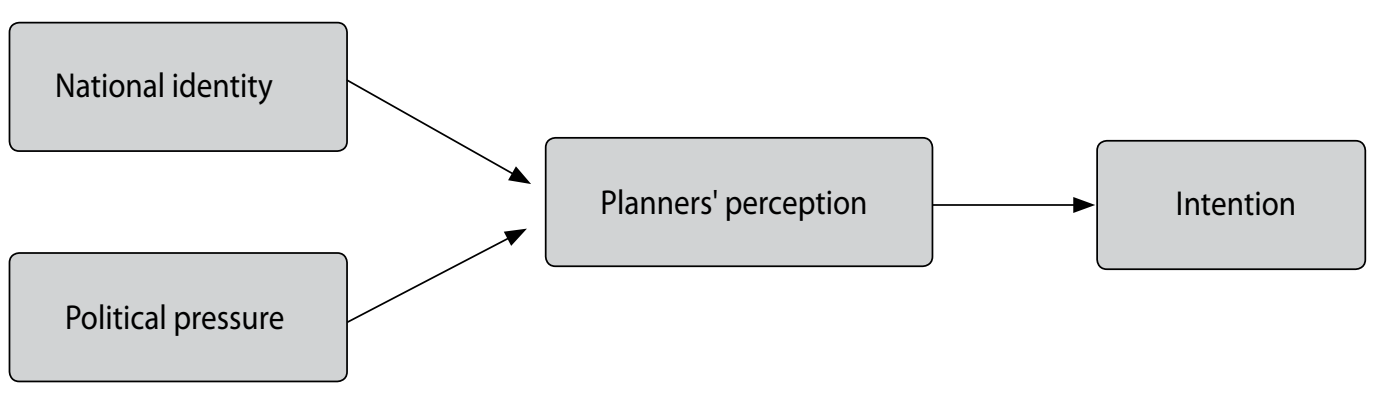

Figure 11: Validated research model 


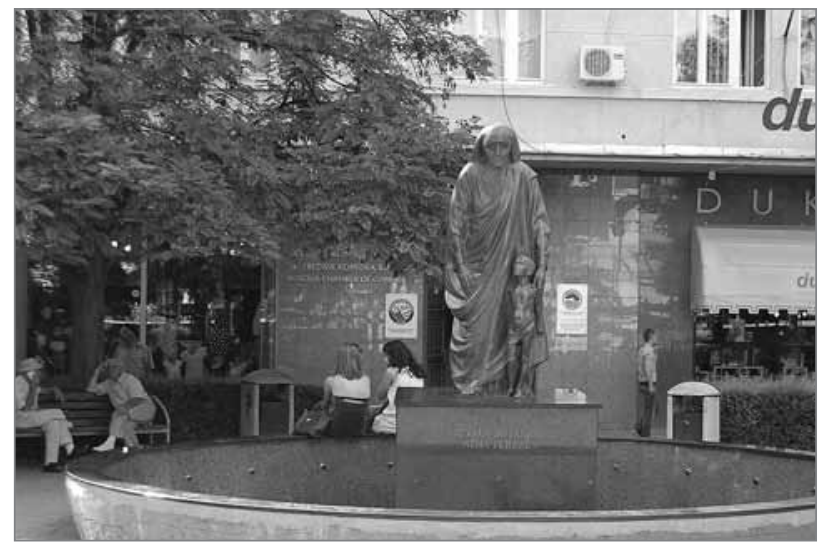

Figure 12: Mother Theresa monument (photo: Arben Asllani).

Anthony King's book Spaces of global cultures (2004) states that high-rise towers are constructions of steel and glass as much as they are constructions of national identity. King's statement is related to $\mathrm{C} 1 s$ statement in this article, who said that the refurbishment of the high-rise tower of the Kosovo Government Building is a representation of Kosovar national identity. In contrast, Philip Allmendinger's study (2001), which seeks to link national identity and urban planning in Scotland, concludes that planning is becoming less a mechanism that reflects national identity and more of a facilitator for economic growth with important symbolic significance of distinctiveness. Accordingly, "it is not the actual physical places which are used to legitimate their nationalist claims to territory but rather their carefully constructed representations of places" (Ashworth \& Graham, 2005: 3). We do not agree with the statement by $\mathrm{C} 1$ that only monumental places and buildings that represent modernism and growth represent national identity. In our opinion, domestic and local spaces inhabited by "ordinary" people also do so. In Prishtina these places are the local cafés and bars filled with young people, which represent young Europeanism. In our view, young Europeanism is in fact the new Kosovar national identity, which is in the making and should find more space in urban planners' perceptions when regulating new spaces in Prishtina.

Hypothesis 2, "If urban planners engage in post-war urban planning or urban planning in a nation with a history of oppression or conflict, then their perceptions will reflect greater ethnic nationalist elements", was rejected by half of the respondents, and only one-fourth think that there is strong direct link between urban planners' exposure to post-war urban planning and their perceptions. This contradicts the findings of Yiftachel (2004), who state that "[s]ettlement systems and cultural landscapes are part of ethnocratic planning regime, [sic] which aims to further the goals of a dominant ethnic group while using a crude rhetoric of 'democratic' majoritarian rule." Eoghan Harris (2003) also found that there is a neverending struggle to ethnicise space as part of planning theory, thus making the nation-state dynamic and internal to planning endeavours, and not a "flat" and unexplored "given", which is particularly the case for "homeland" ethnic groups. Nataša Pichler Milanović (2004) states that all the cities of the former Yugoslavia that have experienced wartime destruction or chaos were shaped by this legacy and are influenced by ethnic nationalist sentiment. Michael Billig (1995) refers to the production of iconic and mundane sites embodied with national ideology as "banal" nationalism. We do not agree with the majority of respondents in the cross-case analysis, who claim that nationalism does not have an effect on urban planners' perceptions. We argue that urban planners are usually influenced by a degree of post-war nationalism and tend to signify national identity not through the nation-building modernism, but through male military heroes (Zahir Pajaziti Square) and statesmen in noble poses in central locations (Ibrahim Rugova Square and Bill Clinton Boulevard). For instance, the Mother Theresa monument is not in a central location and is less visible than others. The Mother Theresa monument is shown in Figure 12.

Hypothesis 3, "If urban planners engage in more mediated social exchanges, then their perceptions on regulating space reflect a greater level of emotional meanings and social constructs", was rejected by two-thirds of the respondents. These results contradict the finding by Mihelic (2008), who states that there is a logical link between social constructs that regulate the relationship between individuals and territory, and that organise their behaviour in the urban sphere and planners' perceptions when regulating space. The social forces working through spatial laws are those that create both differences and constants in settlement forms and configuration of space (Hillier, 2001). We also do not agree with the findings of the respondents in the cross-case analysis because historical, sociopolitical and economic development give rise to new design ideas for new public spaces as a means of working out the implications of the broader social production of space and social construction of space. New perspectives in the social construction of space have emerged as a result of conflicts between different groups in Prishtina that attempt to claim and define these urban places. For some, Zahir Pajaziti Square is a place for military parades on Independence Day, and for others is a place to hold a film festival and display the modernism of the new young Europeans.

Hypothesis 4, "If urban planners work under a major power struggle of political elites, then their perceptions on regulating space reflect more elements of political identity", was accepted by three-quarters of the respondents in the cross-case analysis. This is in line with the study by Mavromatidis and Mavromatidi (2012), who found that individual architects do not have the power to navigate complex political climates in which land is urbanised for a city's future, and are instead influenced by the complex political climate in a country. This is also in line 
with Lefebvre's (1991: 151-152) concept of "[p]roduction of a social space by political power - that is, by violence in the service of economic goals". We agree with Lefebvre's statement, but the details of producing squares and public spaces in Prishtina are more complex and deserve further examination. They are a combination of ethnic nationalism and the political struggle between political parties seeking to win over the electorate through nationalist activity.

Hypothesis 5, "The greater planners' perceptions are when regulating space in a certain way, the greater are their intentions to produce space in that way", is supported in the article by Montserrat Pallares Barbera (2011), who studied Cerdà and his intention to build an urban plan for Barcelona. According to Pallares Barbera (2011), Cerdà constructed a theory of how people should live, based on his social perception of the working class, and on evaluating the needs of the entire population and the need to implement economic activity in a modern "futuristic" city. Planners' intentions can be shaped by their perceptions, which may be historic or political (Higgins, 2001). On the other hand, Ravitz states the contrary, stating that planners' intentions are not affected by their conceptions and perceptions of space, but instead by the attitudes of the middle class majority (Ravitz, 1988, cited in Thomas, 1997). Although Lefebvre's theory of space states that the production of space is a consequence of mere abstraction, we think that planners' intentions are also driven by something "concrete". Lefebvre's theory of space describes planners' intentions strictly on a philosophical basis, whereas Manuel Castells (1997) criticises Lefebvre's theory, stating that the production of space also relies on economic and technological aspects. In the case of Ibrahim Rugova Square, we argue that the planners' intentions were merely driven by nationalist interest and not economics, despite business elites wanting to build a shopping centre there.

\section{Conclusion}

The results of this study of cultural factors affecting planners' perceptions in Prishtina are based on a qualitative analysis of semi-structured interviews with selected urban planners in Prishtina. The confirmation of Hypothesis 1 was not much of a surprise, considering the tendency of national identity factors to affect urban planning not only in countries in transition, but also in developed countries. Although Hypothesis 1 was confirmed by the respondents, we argue that not only squares and monumental places in Prishtina represent national identity, but also new districts with local cafes representing young Europeanism. Surprisingly, Hypothesis 2 was rejected, although there have been limited cases of the regulation of space in Prishtina affected by ethnic nationalist factors. We argue that urban planners are usually influenced by a degree of post-war nationalism and have a tendency to signify national identity not through nation-building modernism, but through male military heroes (Zahir Pajaziti Square) and statesmen in noble poses in central locations (Ibrahim Rugova Square and Bill Clinton Boulevard). The results for Hypothesis 3 show that social constructs do not have any statistically meaningful effect on planners' perceptions. On the other hand, it was not surprising that political pressure was found to have a significant positive effect on planners' perceptions. We argue that it was mostly political pressure that influenced planners' perceptions of what kind of public space to produce and when in Prishtina.

Certain limitations call for future studies on this topic. First, the study was limited to the Prishtina area, hindering generalisation to all of Kosovo. Future studies should focus nationwide, so that the results of this study can better be generalised to all of Kosovo. The use of only qualitative analysis also hampers validity, and a quantitative analysis with a larger sample could be used in addition to qualitative analysis. Moreover, in addition to the variables used in this study, various other factors may affect planners' perceptions when regulating space and their intentions. Future research should focus on other factors that characterise Kosovo, such as the contemporary planning paradigm, the historic context, people's needs and the "closeknit society" paradigm.

\section{Visar Hoxha}

College ESLG, Department of Real Estate Management, Prishtina, Kosovo

E-mail:visar.hoxha@eukos.org

Kaliopa Dimitrovska Andrews

European Faculty of Law in Nova Gorica, Nova Gorica, Slovenia

E-mail: kaliopa.dimitrovska-andrews@evro-pf.si

Alenka Temeljotov Salaj

European Faculty of Law in Nova Gorica, Nova Gorica, Slovenia

E-mail: alenka.temeljotov-salaj@evro-pf.si

\section{References}

Allmendinger, P. (2001) Planning in postmodern times. New York, Routledge.

Appadurai, A. (2000) Spectral housing and urban cleansing: Notes on millennial Mumbai. Public Culture Durham, 12(3), pp. 627-651. DOI: 10.1215/08992363-12-3-627

Ashworth, J. G. \& Graham, J. B. (2005) Senses of place: Senses of time. Burlington, Ashgate.

Banach-Ziaja, M. (2008) The furnishing of the urban public spaces in Poland: Selected issues. Urbani izziv, 19(2), pp. 192-198.

DOI: 10.5379/urbani-izziv-en-2008-19-02-010

Billig, M. (1995) Banal nationalism. London, Sage.

Bizjak, I. (2012) Improving public participation in spatial planning with Web 2.0 tools. Urbani izziv, 23(1), pp. 112-124.

DOI: 10.5379/urbani-izziv-en-2012-23-01-004 
Bourdieu, P. (2001) The forms of capital. In: Granovetter, M. \& Swedberg, R. (eds.) The sociology of economic life, pp. 96-111. Oxford, Westview Press.

Bratina, N. (1997) Perception of open urban space - Bevk Square in Nova Gorica. Urbani izziv, 32-33, pp. 147-151.

DOI: 10.5379/urbani-izziv-en-1997-32-33-007

Castells, M. (1997) The power of identity. Malden, Blackwell.

Castro, C. (2000) Uma viagem pelos mapas do Rio. In: Czajkowski, J. \& Sendyk, F. (eds.) Do cosmógrafo ao satélite - mapas da cidade do Rio de Janeiro, pp. 55-67. Rio de Janeiro, Centro de Arquitetura e Urbanismo, Prefeitura do Rio de Janeiro.

Cooper, D. R. \& Schindler, P. S. (2001) Business research methods. Boston, McGraw-Hill//rwin.

Donnan, H. (2005) Material identities: Fixing ethnicity in the Irish borderlands. Identities: Global studies in culture and power, 12(1), pp. 69-105.

Edensor, T. (2002) National identity, popular culture and everyday life. New York, Oxford.

Eliasson, I. (2000) The use of climate knowledge in urban planning. Landscape and Urban Planning, 48(1), pp. 31-44.

DOI: 10.1016/S0169-2046(00)00034-7

Foucault, M. (1984) L'espace des autres. Architecture, mouvement, continuité, 5(1), pp. 46-49.

Ganis, M. (2009) Planning adaptable and resilient cities: A "small world" paradigm. Paper presented at the International Graduate Research Conference of Universitas 21, 29 November - 5 December, Melbourne, Australia. Typescript.

Gilberti, M. (2013) Rethinking the memorial in a Black Belt landscape: Planning, memory and identity of African-Americans in Alabama. Urbani izziv, 24(1), pp. 144-159. DOI: 10.5379/urbani-izziv-en-2013-24-01-004

Goličnik, B. (2006) Behaviour maps of Ljubljana's squares and parks: New challenges and views of spatial planning and design. Ljubljana, Urban Planning Institute of the Republic of Slovenia.

Güvenç, M. (2011) Constructing narratives of Kurdish nationalism in the urban space of Diyarbakır, Turkey. TDSR, 23(1), pp. 25-40.

Harris, E. (2003) Reaching into a sectarian past. Sunday Times, 11 Feb. 2003.

Harvey, D. (2001) Spaces of capital: Towards a critical geography. New York, Routledge.

Higgins, R. (2001) Displacement: A historical perspective. In: McCafferty, O. (ed.) No place like home, pp. 27-33. Belfast, Tinderbox Theatre Company.

Hillier, B. (2001) A theory of the city as object or how spatial laws mediate the social construction of urban space. Paper presented at the 3rd International Space Syntax Symposium of Georgia Institute of Technology, 7-11 May, Atlanta, GA. Typescript.

Iwata, N. \& Del Rio, V. (2004) The image of waterfront in Rio De Janeiro: Urbanism and social representation of reality. Journal of Planning Education and Research, 24(2), pp. 171-183. DOI: 10.1177/0739456X04267066

Jacobs, J. (2009) The death and life of great American cities: The failure of modern town planning. Ljubljana, Studia Humanitatis.

Jarratt, D. G. (1996) A comparison of two alternative interviewing techniques used within an integrated research design: A case study in outshopping using semi-structured and non-directed interviewing techniques. Marketing Intelligence and Planning, 46(2), pp. 165-178.
Jole, M. (2008) The public of parks: In between observation and action. The example of Paris. Urbani izziv, 19(2), pp. 169-173. DOI: 10.5379/urbani-izziv-en-2008-19-02-007

Jurkovič, N. B. (2014) Perception, experience and the use of public urban spaces by residents of urban neighbourhoods. Urbani izziv, 25(1), pp. 107-125. DOI: 10.5379/urbani-izziv-en-2014-25-01-003

King, D. A. (2004) Spaces of global cultures: Architecture, urbanism, identity. New York, Routledge.

Kolbe, L. (2007) Central and eastern European capital cities: Interpreting www-pages - history, symbols and identity. Planning Perspectives, 22(1), pp. 79-111. DOI: 10.1080/02665430601052088

Lefebvre, H. (1991) The production of space. London, Blackwell.

Low, S. M. (1996) Spatializing culture: The social production and social construction of public space in Costa Rica. American Ethnologist, 24(3), pp. 861-879.

Luna Reyes, F. L. \& Andersen L. D. (2003) Collecting and analyzing qualitative data for system dynamics: Methods and models. System Dynamics Review, 19(4), pp. 271-296. DOI: 10.1002/sdr.280

Márquez, F. (2011) Santiago: Modernisation, segregation and urban identities in the twenty-first century. Urbani izziv, 22(2), pp. 86-97. DOI: 10.5379/urbani-izziv-en-2011-22-02-002

Mavromatidis, L. \& Mavromatidi, A. (2012) Reinventing the doubt of the icon: A virtual case study in a post-Soviet country's capital. Urbani izziv, 23(2), pp. 79-92. DOI: 10.5379/urbani-izziv-en-2012-23-02-001

Mihelič, B. (2008) Maks Fabiani and urbanism in Vienna at the turn of the 19th century. Urbani izziv, 19(1), pp. 129-133.

DOI: 10.5379/urbani-izziv-en-2008-19-01-001

Mumford, L. (1961) The city in history: Its origins, its transformations and its prospects. New York, Harcourt.

Neill, W. J. V. (2004) Urban planning and cultural identity. London, Routledge. DOI: 10.4324/9780203402245

Newman, P. (2000) Changing patterns of regional governance in the EU. Urban Studies, 37 (5-6), pp. 895-908. DOI: 10.1080/00420980050011145

Pallares Barbera, M., Badia, A. \& Duch, J. (2011) Cerdà and Barcelona: The need for a new city and service provision. Urbani izziv, 22(2), pp. 122-136. DOI: 10.5379/urbani-izziv-en-2011-22-02-005

Perry, C. (1998) Processes of a case study methodology for postgraduate research in marketing. European Journal of Marketing, 32 (9-10), pp. 785-802. DOI: 10.1108/03090569810232237

Pichler Milanović, N. (2004) Inter-urban transformations in central and eastern Europe. Urbani izziv, 15(2), pp. 105-111. DOI: 10.5379/urbani-izziv-en-2004-15-02-00

Porteous, J. D. (1977) Environment and behavior: Planning and everyday urban life. Reading, MA, Addison Wesley.

Portugali, J. (2000) Self organization and the city. New York, Springer.

Proshansky, H. M., Ittelson, W. H. \& Rivlin, L. G. (1972) Freedom of choice and behavior in a physical setting. In: Wohlwill, J. F. \& Carson, D. $\mathrm{H}$. (eds.) Environment and the social sciences: Perspectives and applications, pp. 29-43. Washington, American Psychological Association.

Ravitz, M. (1988) Perils of planning as an executive function. American Planning Association Journal, 54(2), pp. 164-165. DOI: 10.1080/01944368808976469

Richardson, M. (1982) Being-in-the-market versus being-in-the-plaza: Material culture and the construction of social reality in Spanish America. American Ethnologist, 9(2), pp. 421-436.

DOI: 10.1525/ae.1982.9.2.02a00120 
Rishbeth, C. (2004) Ethno-cultural representation in the urban landscape. Journal of Urban Design, 9(3), pp. 311-333.

DOI: 10.1080/1357480042000283878

Ristič, M. (2011) Sarajevo warscapes: Architecture, urban space and the politics of ethnic nationalism. Melbourne, University of Melbourne.

Robinson, H. (1994) Perception. London, Routledge.

Rocco, R. (2003) The image of the city Sao Paolo - Identity and crisis. Urbani izziv, 14(2), pp. 108-111.

DOI: 10.5379/urbani-izziv-en-2003-14-02-007

Scott, A. (2014) Beyond the creative city: Cognitive-cultural capitalism and the new urbanism. Regional Studies, 48(4), pp. 565-578.

DOI: 10.1080/00343404.2014.891010

Sennett, R. (1990) The conscience of the eye: The design and social life of cities. New York, Norton.

Strauss, A., \& Corbin, J. (1990) Basics of qualitative research: Grounded theory, procedures and techniques. London, Sage Publications.

Vale, L. (2006). The urban design of twentieth century capitals. In: Gordon, D. L. A. (ed.) Planning twentieth century capital cities, pp. 15-37. London, Routledge.

Wandersman, A. (1979) User participation in planning environments: A conceptual framework. Environment and Behavior, 11(4), pp. 465-482. DOI: $10.1177 / 0013916579114003$

Yiftachel, O. (2004) Reengaging planning theory? Towards "south-eastern" perspectives. Planning Theory. 5(3), pp. 211-222.

DOI: $10.1177 / 1473095206068627$ 